\title{
A Study on the Analysis of the Child Personal Information Processing Status in Mobile Apps : Focused on mobile apps served in Korea
}

\author{
Min-Hyeok Lee, Ji-Yeon Yoo \\ (Department of Information and Security Management Sangmyung University, Republic of Korea)
}

\begin{abstract}
This study aims to empirically examine the reality that a child's personal information can be easily exposed through an app service. As a result of surveying 100 child-targeted apps in the Apple and Google Play App Stores, we collected on average 12 personal information of individuals that included social security numbers and location information that were not collected and clarified for the purpose of collection.

Keywords - Child Personal Information, Mobile Apps, Korea's Act on Promotion of Information and Communications Network Utilization and Information Protection, etc(APICNUIP)
\end{abstract}

\section{INTRODUCTION}

As digital society progresses, various online activities are performed and at the same time, utilization and exposure of personal information is increasing. Especially, as the usage of smartphone apps is becoming more prevalent, the terms required for downloading the apps require excessive personal information that are not related to the function of the app such as contacts, call history, mobile device information--wherein installation of the apps commences only when you agree to the terms [1].

Children are required to provide a variety of personal information about themselves, as much as adults, by actively engaging in online activities.

Children have been treated as vulnerable subjects to be specifically protected by law and policy due to their lack of analytical skills and judgment [2]. The criteria for children dictates the age of under 14 years old in Korea's Act on Promotion of Information and Communications Network Utilization and Information Protection, etc(APICNUIP), but the reason for this is unclear. The criminal underage regulation (Criminal Law Article 9) of the United States, Japan, and Korea is set at under 14 years old at that time, and it is explained that it is applied, but not confirmed.

Children are immature in their ability to judge and evaluate the authenticity of information compared to adults--they are treated indiscriminately without any judgment on the collection, use, or provision of personal information. Children view the Internet as a place of play and socialization, but much of the Internet is related to commercial activities and allows children to be exposed to a variety of information [2] [3]. However, children generally do not understand the consequences of disclosing personal information [3]. The information of these exposed children is likely to be used for a lifetime of exposure and subjects them to an unsafe environment.

For example, in an app marketplace, when you enter an obscene search term that is considered taboo on the Internet, thousands of apps are searched and you can download them at any time, regardless of age. Only one out of ten apps are certified by an adult, for example, an app called "energetic measurement" appears to be at least four years of age [4].

The purpose of this study is to grasp the status of collecting personal information and confirming a legal representative's consent in order to identify the risk of personal information gathering in mobile apps for children.

\section{ANALYSIS OF PERSONAL INFORMATION COLLECTION STATUS IN MOBILE APPS FOR CHILDREN}

\subsection{Survey Outline}

A survey to analyze the status of personal information gathering in mobile apps for childrentargeted apps that are child-grade within the game categories of Apple Appstore and Google Play Store. There were monthly utilization rankings for each app market by analyzing 100 apps from May 5th to 10th, 2014 for six days, excluding $1 \sim 70$ th ranked apps. The reasons for selecting the apps to be surveyed are as follows: "Game/entertainment (77.5\%)" was the main application category of children's ages [5] App selection was easy.

The items to be surveyed are the personal information items to be collected, the purpose of collecting personal information, and the agreement of the legal representative. 


\subsection{Survey Analysis and Results}

The survey analysis is as follows. It is the first personal information item collected from the child and the items of personal information collected based on the principle of restriction of collection of personal information specified in Article 23 of the Act on Promotion of Information and Communication Network Utilization and Information Protection (hereinafter referred to as the "Information and Communication Network Act"). Second, it is the collection of a resident registration number when the child collects personal information. This is based on the restriction of use of the resident registration number 2 of Article 23 of the Act on Promotion of Information and Communications Network Utilization and Information Protection, etc(APICNUIP). Third, we examined the process of confirming the consent of the legal representative required for the provision of personal information of the child and the related process. According to Article 31 of the Information and Communication Network Act, the consent of the legal representative is required to collect the child's personal information. We investigated how the personal information of statutory agents collected at this time is handled [6].

In order to systematically organize survey analysis, personal information collection items in mobile apps are adjusted and arranged based on the user information classification standard used in the smartphone presented in the Privacy Initiative of Japan's Ministry of Internal Affairs and Communications [7].

First of all, the most important categories are "user identification," "third party information," "communication service usage related items." The "user identification" item is divided into "identification information," "information required for login" "information generated using cookie technology," and "contractor unique ID." "Third party information" was defined as "information of a legal representative." In addition, "Information related to the use of communication service" is divided into "Paid service utilization information," "Social information," and "Location information."

Table 1 shows the results of analyzing children's mobile apps collecting personal information items according to the classification criteria.

Table 1. An analysis of collection items of personal information for mobile applications for children

\begin{tabular}{|c|c|c|c|c|}
\hline Division & $\begin{array}{c}\text { Type of } \\
\text { information }\end{array}$ & $\begin{array}{c}\text { Information } \\
\text { included }\end{array}$ & $\begin{array}{c}\text { Applicable } \\
\text { number }\end{array}$ & $\begin{array}{c}\text { Ratio } \\
(\%)\end{array}$ \\
\hline \multirow{2}{*}{$\begin{array}{c}\text { User } \\
\text { identification }\end{array}$} & \multirow{2}{*}{$\begin{array}{c}\text { Identification } \\
\text { information }\end{array}$} & Name & 61 & $68 \%$ \\
\cline { 3 - 6 } & & Dender & 35 & $39 \%$ \\
\cline { 3 - 6 } & & Date of birth & 26 & $29 \%$ \\
\hline
\end{tabular}

\begin{tabular}{|c|c|c|c|c|}
\hline Division & $\begin{array}{c}\text { Type of } \\
\text { information }\end{array}$ & $\begin{array}{l}\text { Information } \\
\text { included }\end{array}$ & $\begin{array}{c}\text { Applicable } \\
\text { number }\end{array}$ & $\begin{array}{c}\text { Ratio } \\
(\%)\end{array}$ \\
\hline & & Phone number & 46 & $51 \%$ \\
\hline & & $\begin{array}{c}\text { Mobile phone } \\
\text { number }\end{array}$ & 50 & $56 \%$ \\
\hline & & E-mail & 71 & $79 \%$ \\
\hline & & Zip code & 8 & $9 \%$ \\
\hline & & Address & 57 & $63 \%$ \\
\hline & & $\begin{array}{c}\text { Social security } \\
\text { numbers } \\
\text { (Korea's } \\
\text { resident } \\
\text { registration } \\
\text { number) }\end{array}$ & 19 & $21 \%$ \\
\hline & \multirow{3}{*}{$\begin{array}{c}\text { Information } \\
\text { required to } \log \\
\text { in ID }\end{array}$} & ID & 41 & $46 \%$ \\
\hline & & Password & 25 & $28 \%$ \\
\hline & & Nickname & 39 & $43 \%$ \\
\hline & \multirow{5}{*}{$\begin{array}{l}\text { Information } \\
\text { generated } \\
\text { using cookie } \\
\text { technology }\end{array}$} & Cookie & 27 & $30 \%$ \\
\hline & & $\begin{array}{c}\text { Visit date and } \\
\text { time }\end{array}$ & 9 & $10 \%$ \\
\hline & & Access log & 48 & $53 \%$ \\
\hline & & $\begin{array}{c}\text { Service usage } \\
\text { history }\end{array}$ & 51 & $57 \%$ \\
\hline & & Bad record & 14 & $16 \%$ \\
\hline & \multirow{3}{*}{$\begin{array}{l}\text { Contractor } \\
\text { unique ID }\end{array}$} & $\begin{array}{c}\text { Terminal } \\
\text { information }\end{array}$ & 68 & $76 \%$ \\
\hline & & IP address & 40 & $44 \%$ \\
\hline & & $\begin{array}{c}\text { IEMI (Device } \\
\text { ID) }\end{array}$ & 18 & $20 \%$ \\
\hline $\begin{array}{l}\text { Third party } \\
\text { information }\end{array}$ & $\begin{array}{c}\text { Legal } \\
\text { Representative } \\
\text { Information }\end{array}$ & \begin{tabular}{|c|} 
Legal \\
Representative \\
Information
\end{tabular} & 48 & $53 \%$ \\
\hline \multirow{10}{*}{$\begin{array}{c}\text { Information } \\
\text { related to use } \\
\text { of } \\
\text { communication } \\
\text { service }\end{array}$} & \multirow{6}{*}{$\begin{array}{l}\text { Paid service } \\
\text { usage } \\
\text { information }\end{array}$} & Card mission & 39 & $43 \%$ \\
\hline & & Card number & 39 & $43 \%$ \\
\hline & & Name of bank & 5 & $6 \%$ \\
\hline & & $\begin{array}{l}\text { Account } \\
\text { number }\end{array}$ & 5 & $6 \%$ \\
\hline & & $\begin{array}{l}\text { Account } \\
\text { holder }\end{array}$ & 5 & $6 \%$ \\
\hline & & $\begin{array}{l}\text { Payment } \\
\text { record }\end{array}$ & 49 & $54 \%$ \\
\hline & $\begin{array}{c}\text { Social } \\
\text { information }\end{array}$ & $\begin{array}{c}\text { SNS } \\
\text { information }\end{array}$ & 30 & $33 \%$ \\
\hline & & $\begin{array}{l}\text { GPS location } \\
\text { information }\end{array}$ & 30 & $33 \%$ \\
\hline & $\begin{array}{l}\text { Location } \\
\text { information }\end{array}$ & $\begin{array}{c}\text { Base station } \\
\text { location } \\
\text { information }\end{array}$ & 4 & $4 \%$ \\
\hline & & $\begin{array}{c}\text { About WIFI- } \\
\text { AP }\end{array}$ & 4 & $4 \%$ \\
\hline
\end{tabular}


As a result, the average amount of personal information collected by mobile apps for children was 12.2 , and some apps collected up to 24 items.

When looking at the personal information items to be collected, e-mail (79\%) was the most common, and information on the handset $(76 \%)$, name $(68 \%)$, address $(63 \%)$, access logs $(53 \%)$, and telephone numbers $(51 \%)$. Most of the purpose of collecting these personal information is not clearly shown. Other identification information, social information, location information, and the like were collected.

In the case of the mobile game app, "login information" and "information generated by using cookie technology," which are generated during the service use, however, in the case of a mobile app to be surveyed, it is defined as "ID," "representative nickname," "password," "phone number (or one of mobile phone number)," "e-mail."

In particular, $21 \%$ of apps collecting resident registration numbers are restricted from collection and use.

Only $48 \%$ of the apps that confirm and deal with the legal representative's consent were found and companies that did not specify the process of personal information processing of a legal representative were also found.

\section{Conclusion}

This study investigates personal information items collected by mobile apps for children. The purpose of this study is to clarify whether the purpose of collecting personal information is clear and to check whether the consent of the legal representative is confirmed.

As a result of the analysis, more personal information items were collected than necessary and the purpose of collection was not revealed. In particular, it appears that there is a mobile app that collects the child's social security number without clearly identifying the purpose of the collection. Also, it has been found that the procedure of confirming consent of the legal representative is not performed properly.

Personal information of a child whose judgment is inexperienced should be protected socially until the child becomes an adult who can self-judge, expose, and provide his/her personal information under mature circumstances. Although the institutional apparatus for this is provided as the right of the legal representative in the Article 31 of the Act on Promotion of Information and Communications Network Utilization and Information Protection, etc(APICNUIP), a reality check on the confirmation of the legal representative's consent must be made and the way of limiting the personal information of the child that can be collected through the legal representative does exactly this. In addition, it is necessary to discuss in detail the "right to be forgotten" regarding a child's personal information.

There are two major drawbacks to this study. First, it was only a survey of personal information. In addition to collection, the use of personal information according to purpose and the empirical analysis related to this were not done. For this reason, I would like to carry out this study by continuing to make an empirical analysis and an analysis on the parent of the child, as well as to investigate the risks and related cases of collecting personal information of children.

\section{REFERENCES}

[1] Seoul Economic, [Inside the Issues] Requires a one-sided consent on the use of personal information... privacy concerns, Jan 13, 2013.

[2] FTC, Staff report: public workshop on consumer privacy on the global information infrastructure, 1996.

[3] Office of the Ombudsman, There ought to be a law: protecting children's online privacy in the 21 st century, A Discussion paper for Canadians by the Working Group of Canadian Privacy Commissioners and Child and Youth Advocates, 2009.

[4] JoongAng Ilbo, Elementary school students see the AO(Adults Only) application... shock, Oct 17, 2012.

[5] Korea Internet \& Security Agenc, Survey on the mobile internet usage in the 2013, 2013.

[6] Korea Communication Commission, Act on Promotion of Information and Communications Network Utilization and Information Protection, etc(APICNUIP), 1986.

[7] Japan 's Ministry of Internal Affairs and Communications, Smartphone privacy initiative, 2012. 